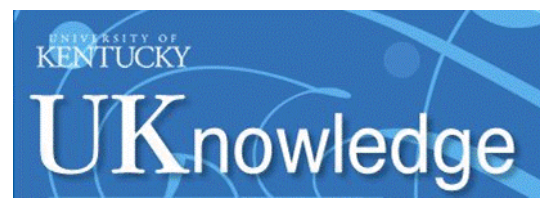

University of Kentucky

UKnowledge

\title{
Intellectual Freedom and Freedom of Speech: Three Theoretical Perspectives
}

Shannon M. Oltmann

University of Kentucky, shannon.oltmann@uky.edu

Follow this and additional works at: https://uknowledge.uky.edu/slis_facpub

Part of the Library and Information Science Commons

Right click to open a feedback form in a new tab to let us know how this document benefits you.

\section{Repository Citation}

Oltmann, Shannon M., "Intellectual Freedom and Freedom of Speech: Three Theoretical Perspectives" (2016). Information Science Faculty Publications. 30.

https://uknowledge.uky.edu/slis_facpub/30

This Article is brought to you for free and open access by the Information Science at UKnowledge. It has been accepted for inclusion in Information Science Faculty Publications by an authorized administrator of UKnowledge. For more information, please contact UKnowledge@lsv.uky.edu. 


\section{Intellectual Freedom and Freedom of Speech: Three Theoretical Perspectives}

Digital Object Identifier (DOI)

https://doi.org/10.1086/685402

\section{Notes/Citation Information}

Published in The Library Quarterly, v. 86, no. 2, p. 153-171.

(c) 2016 by The University of Chicago. All rights reserved.

The copyright holder has granted the permission for posting the article here. 


\title{
Intellectual Freedom and Freedom of Speech: Three Theoretical Perspectives
}

\section{Shannon M. Oltmann}

\begin{abstract}
Freedom of speech encompasses not only a right to express oneself but also a right to access information. This right is particularly pertinent to libraries, whose mission is often focused on enabling and expanding access to information. Libraries can support this activity with a theoretical background that draws upon the three predominant jurisprudential theories of freedom of speech: the marketplace of ideas, democratic ideals, and individual autonomy. In this article, each of these theories is explained and then applied to the library context, creating a starting place for further investigation and application of these judicial theories to information access.
\end{abstract}

l

ntellectual freedom (IF) is a core value of modern American libraries, particularly public libraries (Gorman 2000). The American Library Association (ALA) has utilized IF as a cornerstone upon which to build policies regarding a wide array of issues, including academic freedom, biometrics, Internet access, confidentiality, Internet filters, graphic novels, hate speech, privacy, RFID, surveillance, and terrorism (ALA 2014b). The ALA defines IF as "the right of every individual to both seek and receive information from all points of view without restriction. It provides for free access to all expressions of ideas through which any and all sides of a question, cause or movement may be explored" (ALA 2014C, par. 1).

Much work has been done to examine and explain the ethical basis of IF, particularly in the Library Bill of Rights (e.g., Fricke, Mathiesen, and Fallis 2000; Doyle 2001; Fallis and Mathiesen 2001; Doyle 2002; Hauptman 2002; Budd 2006; Fallis 2007). These scholars have debated whether application of IF is best done with a utilitarian, deontological, or communitarian ethical approach. By better understanding the ethical basis (or presuppositions) of the Library Bill of Rights and of IF more generally, these authors seek to guide behavior - to understand and enact the most ethical approaches to IF. Examining the ethical basis of IF is a very useful and practical endeavor.

Library Quarterly: Information, Community, Policy, vol. 86, no. 2, pp. 153-171. (C) 2016 by The University of Chicago. All rights reserved. $0024-2519 / 2016 / 8602-0002 \$ 10.00$ 
However, the theoretical basis (as opposed to the ethical basis) of IF is rarely articulatedor, as Emily Knox (2014) said, the prevalent case studies "do not emphasize theory and analysis" (17). Similarly, John Buschman (2007) noted that very little of the LIS literature that mentions democracy is peer reviewed. For the study reported in this article, a search for relevant terms was conducted in two databases: Library, Information Science, and Technology Abstracts and Library Literature and Information Science Full Text. The search terms were entered, with quotation marks, for any field. As table 1 illustrates, there are few peer-reviewed articles on the topic of freedom of speech. Although the individual search terms "marketplace of ideas," "democracy," and "autonomy" show a larger number of articles, when those terms are combined with "freedom of speech," the results drop sharply.

This gap in the literature leaves arguments for IF weak and underdeveloped. For example, Paul R. Burden (2000) discussed, in a typical article, the importance of IF and access to information, noting that "the best way to show the uselessness and fallibility of incorrect beliefs or ideas is not to keep them out of sight, but rather to hold them up to the light of day [and] scrutinize them" (49). He made an implicit reference to the freedom-of-speech theory of the marketplace of ideas (discussed later) but left this theory undeveloped. Explicitly founding his article on this theory would make the arguments more compelling to those both in and outside LIS.

In addition, libraries themselves would benefit from a stronger theoretical basis for IF. They will be standing on firmer ground, buttressed by these theories, when they advocate for IF. The theoretical basis provides more context and substance to IF, which should enable libraries to more successfully defend IF to their boards, patrons, and communities. Drawing upon the marketplace-of-ideas theory, a public library could better explain why it collects a wide range of perspectives (including, perhaps, unpopular ones) on particular issues.

Discussing "theory" in relation to IF can be fraught because the nature of theory in LIS research is contested (McGrath 2002; McKechnie and Pettigrew 2002; Bates 2005). Perhaps as a result, some have argued for a broader understanding of theory in LIS. For example, Michael

Table 1. Search Terms Related to Freedom of Speech Theories

\begin{tabular}{lc}
\hline Search Term & Number of Articles Found \\
\hline "Freedom of speech" & 325 \\
"Marketplace of ideas" & 10 \\
"Marketplace of ideas" and "freedom of speech" & 0 \\
Democracy & 2,394 \\
Democracy and "freedom of speech" & 23 \\
Autonomy & 531 \\
Autonomy and "freedom of speech" & 1 \\
\hline
\end{tabular}


Buckland (1991) defined theory "in the broad sense of a description or explanation of the nature of things, not in the more restricted sense, used in some sciences, of denoting fundamental laws formally stated and falsifiable" (18). This article adopts Buckland's (1991) approach to theory; the jurisprudential ${ }^{1}$ perspectives discussed later may not fit a traditional scientific understanding of theory yet are valid, valuable ways to describe and analyze IF and are treated as theoretical perspectives. Rodney A. Smolla (2005) suggested that " free speech theory' refers to various attempts by jurists and scholars to supply answers to what might be called the Why question implicit in the First Amendment. Why does the First Amendment exist? What is the purpose of freedom of speech?" (2-3, emphasis in original). Many social science theories likewise attempt to answer "why" questions.

This article proposes to rectify the theoretical gap frequently encountered in discussions of IF by explicitly connecting it with freedom of speech and the three predominant jurisprudential theories of freedom of speech. First, the connections between librarianship, IF, the right to access information, and freedom of speech are explored by examining relevant court cases, which demonstrate that IF is in fact tightly coupled with freedom of speech. The court cases are discussed independently of the theories because, in most cases, the courts' findings do not refer directly to the theories. Next, the article discusses the three theories of freedom of speech - the marketplace of ideas, democracy relying on freedom of speech, and individual autonomy. Within this section, the specific relevance of each theory to libraries is also discussed. (The arguments in this article are likely most applicable to public libraries, but they are also relevant for school and academic libraries, and some special libraries, as well.) Finally, the article concludes with a brief discussion of ways to further investigate or apply these theories.

The article argues that it is worthwhile to explore arguments used to support freedom of speech because, by extension, these same arguments are applicable to information access and IF. These legal theories provide some of the strongest analysis and explication of freedom of speech (and information access) and have been foundational — though often only implicitlyfor how LIS scholars conceptualize freedom of speech and information access.

\section{Libraries and the Right to Access Information}

The relationship of libraries and the right to access information can be found in case history. In the court case Kreimer v. Bureau of Police for Morristown, a homeless person successfully chal-

1. Much legal and jurisprudence theory is based upon an examination of court decisions and writings rather than on explicitly stating hypotheses, variables, and findings, yet they remain important examples of investigations into freedom of speech and information access. As the Blackwell Guide to the Philosophy of Law and Legal Theory states, legal theory is "an enterprise that has tended to concentrate on rationalizing and legitimating whole departments of legal doctrine" (Edmundson 2005, 1; see also Blasi 1977; Shiffrin 1990; and Barzun 2007). Legal theories include different ways to understand, interpret, and apply the concept of "freedom of speech." 
lenged a library's patron-conduct rules as too restrictive. ${ }^{2}$ The Second District Federal Court said, "The First Amendment does not merely prohibit the government from enacting laws that censor information, but additionally encompasses the positive right of public access to information and ideas" (1255). The court added that a public library is "the quintessential locus of the receipt of information" (1256), and thus the defendant could not be barred from the library. Similarly, Bernard Bell (2001) argued that "libraries are the archetypal traditional government-funded loci for acquiring knowledge just as streets and parks are by traditional archetypal government-funded loci for speaking" (221, emphasis added; see also Blitz 2006).

A 2002 case in Colorado, Tattered Cover $v$. City of Thornton, in which a bookstore challenged an overly broad search warrant seeking purchase information, found that citizens have a right to receive ideas and information. ${ }^{3}$ The court further held that "it is well established that [the First Amendment] safeguards a wide spectrum of activities, including . . . most importantly to this case, the right to receive information and ideas. . . Without the right to receive information and ideas, the protection of speech under the United States and Colorado Constitutions would be meaningless." ${ }^{4}$

This case was followed by another in 2003, Neinast $v$. Board of Trustees of the Columbus Metropolitan Library, in which a barefoot defendant challenged his expulsion from the public library. ${ }^{5}$ The court explicitly recognized a right to access information that "includes the right to some level of access to a public library, the quintessential locus of the receipt of information” (590). These library-related cases dealt with individuals' rights to freely access information in public libraries.

A more recent case that tested the prima facie constitutionality of the Children's Internet Protection Act (CIPA), United States v. American Library Association, also focused upon access to information. In this case, the concerns were about minors accessing inappropriate information and adults' ability to freely and easily access whatever legal information they wanted. ${ }^{6}$ Although the constitutionality of Internet filtering was upheld, Anne Klinefelter (2010) noted that "eight of the Justices found the ability of adult patrons to gain access to protected Internet speech to be important to the constitutionality of the library's use of Internet filters" (362).

Marc J. Blitz (2006) argued that libraries serve a unique institution "where access for the public follows logically from the mission of the institution" (816). In his article, he elaborated that the access to information provided by libraries is essential because it allows "thought experiments" in living that are often not possible with modern social norms and expectations.

\footnotetext{
2. Kreimer v. Bureau of Police for Morristown, 958 F. 2d 1242 (1992).

3. Tattered Cover v. City of Thornton, 44 P. 3d 1044 (2002).

4. Tattered Cover v. City of Thornton, 44 P. 3d 1044 (2002), 1052-1053.

5. Neinast v. Board of Trustees of the Columbus Metropolitan Library, 346 F. 3d 585 (2003).

6. United States v. American Library Association, (02-361) 539 US 194. 201 F. Supp. 2d 401 (2003).
} 
Blitz explained that libraries provide places where people can access diverse information, including information that may not be tolerated within their community or culture; people have the privacy and the intellectual space to "try on" new ideas and ways of thinking. This is uniquely possible in a library, Blitz said, because the library places "information seekers, who are normally dependent on speakers, in the position of being independent initiators of intellectual explorations" (844). Libraries are a neutral conduit between speakers (even those from the distant past, whose words are preserved) and information seekers.

This role is one that libraries have long recognized and valued, though it is important to note that the "neutrality" of libraries is contested (see, e.g., Jensen 2004; Good 2006; Jaeger et al. 2013). The foundational policy and position documents of the ALA all emphasize the importance of equal and free access to information (e.g., Burden 2000; Krug 2002; Berry 2004; ALA 2014a, 2014b, 2014c, 2014d, 2014e). The close connection between IF and information access has been recognized by numerous scholars (Jones 1999; Burden 2000; Kranich 2001; Krug 2002; Jaeger and Burnett 2005; Burnett, Jaeger, and Thompson 2008; Mathiesen and Fallis 2008; Thompson 2008). Fundamentally, IF protects individuals' right to access information, one of the core aspects of freedom of speech; this relationship is elaborated upon in the next section.

\section{The First Amendment Right to Access Information}

Information access is a core component of the broader right of freedom of speech. This section traces the development of this concept through several key court cases. The First Amendment prohibits Congress from "abridging the freedom of speech" of citizens. Over time, freedom of speech has been interpreted to include the ability or right to receive speech. As Smolla (2005) noted, "While we usually think of the First Amendment as empowering speakers to speak, it might well be understood as embracing a concomitant right of listeners to listen, viewers to view, or readers to read" (2-72). This right to access information exists "even when unconnected to any specific willing speaker or any specific instance of speech" (Blitz 2006, 818). Essentially, the argument is that freedom of speech is impossible or valueless without the right or ability to access that speech (Emerson 1970; Bollinger 1986; Smolla 1993; Jones 1999; Burden 2000; Mart 2003; Braddon-Mitchell and West 2004). Extensive support for this connection can be found in American jurisprudence concerning the First Amendment and citizens' freedom of speech.

A brief review of relevant court cases will demonstrate the centrality of information access to freedom of speech. The earliest cases to address access to information were Martin $v$. City of Struthers and Thomas $v$. Collins, which established that access was "necessarily correlative" to freedom of speech. ${ }^{7}$ In Griswold v. Connecticut, a married couple sought contraceptive information, and the Supreme Court ruled that their access to such information was protected

7. Martin v. City of Struthers, 319 U.S. 141 (1943); Thomas v. Collins, 323 U.S. 515 (1945). 
under the First Amendment. ${ }^{8}$ In fact, even the right to receive obscene material is protected (Stanley v. Georgia, 1969). .' Susan N. Mart (2003) noted that "by 1969, the right to receive information had become a fundamental right" (178-179). In one of the few Supreme Court cases dealing with libraries (Board of Education $v$. Pico), a plurality of justices said that a right to access information was "an inherent corollary of the rights of free speech." ${ }^{10}$ Although not a majority finding, this was still valuable for the right to receive and access information. Blitz (2006) concluded that "it is now well established that the First Amendment protects not only the rights of people to engage in speech but also the right of audiences to receive it" (800).

The US courts have found the right of access to be a corollary of the First Amendment for two reasons. First, the right to receive ideas and information follows naturally from the speaker's right to disseminate them; without someone to receive the ideas, the right of free speech is incomparably diminished (Lamont $v$. Postmaster General). ${ }^{11}$

Second, the right to receive information is "a necessary predicate to the recipient's meaningful exercise of his own rights of speech, press, and political freedom."12 In order to produce speech, one must have access to others' speech, which can then inform or shape one's own ideas (Scanlon 1972; Balkin 2004). In fact, Thomas I. Emerson (1970) argued that "the right to read, listen, or see is so elemental, so close to the source of all freedom, that one can hardly conceive of a system of free expression that does not extend it full protection" (6). In this perspective, receiving or accessing information and expressing information "are properly viewed as two halves of the same whole" (Cohen 1996, 1006; see also Coase 1974; Smolla 1992; Napoli 1999).

Set in context, these court cases define and demonstrate the connection between information access and freedom of speech. This connection indicates that the freedom-of-speech theories are applicable to information access and IF.

\section{Theories of Freedom of Speech}

There are several theories that support and explain the US conceptualization and jurisprudence of freedom of speech (see, e.g., Schauer 1982; Post 2011b, 619; Shiffrin 2011), but three predominate: the marketplace of ideas, democracy, and individual utility, as depicted in table 2 (Blasi 1977; Bollinger 1986; Heckart 1991; Smolla 1992; Ross 1999; McDonald 2004; Smolla 2005; Blitz 2006; Klinefelter 2010; Post 2011a). Several scholars note that utilizing multiple theories for freedom of speech is reasonable, even powerful, because the Supreme Court itself does not have a single overarching theory (Schauer 1982; Shiffrin 2011). Thus, this article takes the position that the three theories discussed here - the marketplace of ideas, democracy, and

\footnotetext{
8. Griswold v. Connecticut, 382 U.S. 479 (1965).

9. Stanley v. Georgia, 394 U.S. 557 (1969).

10. Board of Education v. Pico, 457 U.S. 853 (1982).

11. Lamont v. Postmaster General, 381 U.S. 301 (1965).

12. Board of Education v. Pico, 457 U.S. 853 (1982), 867.
} 
Table 2. Predominant Jurisprudential Approaches to Freedom of Speech

\begin{tabular}{ll}
\hline Theoretical Approach & \multicolumn{1}{c}{ Key Arguments } \\
\hline The marketplace & - Ideas should compete with one another in a marketplace, in which \\
of ideas & the best (most truthful) ideas will eventually be adopted. \\
& - Speakers are analogous to sellers and listeners to buyers/consumers. \\
& - Full or partial truth can be found in most ideas, so all should be heard. \\
& - Even falsehoods can aid the search for truth by strengthening true \\
& arguments. \\
- Ideas are evaluated through ongoing, community-engaging process. & - Free speech is essential to promoting and ensuring democracy. \\
- Free speech is implicated in both civic participation and public & deliberation. \\
- It ensures that citizens know their rights and can exercise them. & - Free speech keeps government accountable and responsive. \\
- It facilitates good collective decision making. \\
- Freedom of speech (thought) is essential to self-fulfillment and \\
development. \\
- It can empower individuals. \\
- Free speech is an end in itself.
\end{tabular}

individual utility—are all valuable, important, and useful ways to theorize freedom of speech and access to information.

\section{The Marketplace of Ideas}

The "marketplace of ideas" is one of the predominant theories concerning the right to freedom of speech (Hopkins 1996; Gordon 1997; Napoli 1999; Braddon-Mitchell and West 2004; Smolla 2005). Although they are sometimes discussed separately (e.g., Raikka 2003), the marketplace of ideas and the search for truth are so interlaced that they are usually discussed together and treated as a single approach to freedom of speech (Emerson 1970; Schauer 1986; Hopkins 1996; Blasi 1997; Gordon 1997; Chevigny 1998; Blasi 2004; Braddon-Mitchell and West 2004; Riley 2005; Barzun 2007). As a metaphor, the marketplace of ideas is more fruitful and useful when modified with the "search for truth."

In On Liberty, John Stuart Mill ([1869] 1921) argued that allowing free speech is the best way to ensure the advancement of truth. The marketplace of ideas is a (figurative) place in which truth emerges from an engaging, interactive competition. In this view, the open and free exchange of ideas will lead to the eventual adoption of the best ideas, which prevail over falsehoods. Mill's ideas were echoed in Justice Oliver Wendell Holmes's famous dissent in Abrams v. United States..$^{13}$ This dissent, arguing that the government did not have the right to silence 
opposition, is the foundation of US jurisprudence about freedom of speech. Holmes argued that the best test of truth is "the power of the thought to get itself accepted in the competition of the market, and that truth is the only ground upon which [citizens'] wishes safely can be carried out. That at any rate is the theory of our Constitution" (630).

In this metaphor, "speakers are analogous to producers and sellers, [and] listeners and viewers are analogous to buyers and consumers" (Riley 2005, 164). Speakers offer opinions, ideas, and information; listeners evaluate the multiple ideas available and choose what they want. In Mill's and Holmes's view, they should choose the best, the most truthful, information. Foundational freedom-of-speech cases, such as Lamont v. Postmaster General and Griswold v. Connecticut, utilized the marketplace of ideas to explain why individuals' freedom of speech needs to be protected. In Lamont $v$. Postmaster General, which was about post offices retaining foreign communist mailings, Justice William Brennan articulated the relationship between freedom of speech and access to information, saying, "It is true that the First Amendment contains no specific guarantee of access to publications. However, the protection of the Bill of Rights goes beyond the specific guarantees to protect from congressional abridgment those equally fundamental personal rights necessary to make the express guarantees fully meaningful. ... The dissemination of ideas can accomplish nothing if otherwise willing addressees are not free to receive and consider them. It would be a barren marketplace of ideas that had only sellers and no buyers." ${ }^{14}$

Brennan thus explained that freedom of speech has little power if others cannot receive, or access, that speech. A marketplace without buyers, he speculates, would soon become a marketplace without sellers, thus eliminating the purpose of and need for a market. The ability to "buy" - to access information - is necessary to constitute a market. As Phillip M. Napoli (1999) noted, "By the mid-1960s, the marketplace metaphor had fully crystallized into a concise expression of a key dimension of the First Amendment" (155).

Jill Gordon (1997) warned that markets respond primarily to "forces of power whether it be in terms of wealth, influence, or sheer numbers, and truth is not necessarily generated from any of these sources" (241). In other words, market competition will not necessarily, and in fact is unlikely to, lead to the emergence of truth.

Vincent Blasi (1997), a noted First Amendment scholar, acknowledged the problems of using the market as a metaphor, but argued that the marketplace of ideas should be understood symbolically; he made this argument because he saw this analogy as the best explanation for freedom-of-speech jurisprudence. Blasi noted that the social values of ideas and information are not captured in economic descriptions of markets; instead, he demonstrated that Holmes had a more nuanced market in mind. He wrote, "Ideas should be evaluated the way consumer goods and services are: not by any kind of political or intellectual authority but

14. Lamont v. Postmaster General, 381 U.S. 301 (1965), 308. 
rather by an open-ended process that measures and integrates the ongoing valuations of all the individuals who comprise the relevant community" (4).

Thus, individuals, through their consideration, rejection, and selection of ideas, demonstrate which ideas have the most currency, power, and importance (or, in Mill's conception, truth). In this manner, ideas are subjected to "a vibrant, brutal weeding-out process analogous to the functions markets for goods and services perform" (Blasi 2004, 24). Blasi interpreted the marketplace, then, as a description of how ideas can be challenged and contested, resulting in their acceptance or rejection. (In fact, this weeding-out process is a widely recognized approach; Eugene Volokh (2011) noted that "the constant process of questioning, testing, updating, and sometimes replacing received wisdom is the hallmark of good science and good history" [597].)

As Blasi cautioned, the market should be understood not in terms of economics but as a metaphor. Thus, Gordon's (1997) concern that truth does not survive under economic market conditions misses the point: Holmes was suggesting that we submit ideas not to an economic market but rather to similar processes, uncontrolled by authority and open to collective evaluation (see also Smolla 2005). Wat W. Hopkins (1996) provided some empirical evidence that this perspective of free speech has been taken up by the Supreme Court. After surveying how the Supreme Court employed the phrase "marketplace of ideas," Hopkins noted that "members of the Court have referred to a multitude of marketplaces and have indicated that these marketplaces are controlled by differing technology, geography, content, or other factors" $(45)$. In other words, there are multiple marketplaces, which are overlapping, disorganized, and unpredictable.

The marketplace of ideas has endured since being introduced into American jurisprudence by Holmes. The metaphor has been used in at least 125 opinions in 97 cases involving free-speech issues between 1919 and 1995 (Hopkins 1996). In addition, the marketplace of ideas has gained acceptance beyond legal theorists, "to the extent of gaining traction in popular culture" (Blasi 2011, 538). Despite this acceptance in popular culture, the marketplace of ideas is still rigorously debated and analyzed in hundreds of scholarly and legal articles and books. It is possible that its popularity has clouded its meaning and application.

\section{Libraries as Marketplaces of Ideas}

When the LIS literature promotes IF or counters censorship by arguing for a wide circulation of diverse ideas, the marketplace of ideas is implicated. In Foundations of Library and Information Science, Richard E. Rubin (2004) suggested that "people and society as a whole are changed, and in the long run, improved by ideas, no matter what format of these ideas" (313), employing the marketplace of ideas theory to argue for broad information access in libraries.

Ronald J. Heckart (1991) argued that librarians have "embraced the essential content" of the marketplace-of-ideas metaphor (491), both in essential professional documents and in their 
daily practices. According to his perspective, librarians adopt two conflicting roles with regard to the marketplace of ideas: on one hand, librarians strive to be "neutral facilitators" of the search for truth, enabling patrons to enact their right to access information. On the other hand, librarians occasionally intervene in that market "when market forces would otherwise exclude new, unorthodox, and controversial ideas" (497). They intercede, said Heckart, to increase the circulation of information and improve the marketplace of ideas. This can be seen as an instance of the marketplace as Blasi (1997) depicted it: not under the control of economic forces but instead operated through social forces. Librarians function as rights facilitators, providing the means by which patrons can access information and utilize this aspect of freedom of speech.

\section{Democracy Needs Free Speech}

In both the LIS and legal literature, the marketplace of ideas is frequently justified by referring to the argument from democracy, the second predominant theory concerning freedom of speech (and one that is "well entrenched in the American constitutional tradition" [Smolla 2005, 2-26.2]). According to this line of thinking, freedom of speech is crucial because it enables the circulation of ideas and accountability necessary to a healthy democracy. Emerson (1970) explained that "the governed must, in order to exercise their right of consent, have full freedom of expression both in forming individual judgments and in forming the common judgment" (7). Citizens of a democracy need as much information as possible in order to make good political decisions (Chafee 1941; Meiklejohn 1961; Emerson 1970; Bork 1971; Schauer 1982; Smolla 1992; Chambers 2003; Balkin 2004; Barzun 2007).

Most formulations of the democracy theory of free speech are concerned primarily or exclusively with political speech, any “citizen's speech, press, peaceable assembly, or petition, whenever those activities are utilized for the governing of the nation" (Meiklejohn 1961, 256). The speech that is most directly connected to democracy is the most strongly protected, under this theory. Critics have charged that this theory applies only to political speech, overlooking or discounting many other types of speech and forms of expression, particularly popular culture (Schauer 1982, 1986; Balkin 2004). Alexander Meiklejohn, however, extended political speech to include education, philosophy and science, general public discussions, and literature and the arts, though it is unclear how far such an extension can stretch without weakening the emphasis on democracy (Schauer 1986; Smolla 2005). The Supreme Court has rejected the idea that First Amendment protection is only for political speech (while also recognizing the importance of political speech; Smolla 2005).

Regardless of the specific types of speech that may be covered by this theory, "public deliberation [is seen] as a cornerstone of participatory democracy and representative government" (Delli Carpini, Cook, and Jacobs 2004, 316). Smolla (1992) explained that there are five ways that self-governance and free speech are connected. First, freedom of speech is "a 
means of participation, the vehicle through which individuals debate the issues of the day, cast their votes, and actively join in the processes of decision-making" inherent in a democracy (12). Second, in an argument derivative of the marketplace of ideas, freedom of speech aids in the pursuit of political truth. Third, free speech can aid majority rule by "ensuring that collective policy-making represents, to the greatest degree possible, the collective will" (12). Smolla's fourth point was that free speech can be a restraint on state tyranny and corruption. Finally, free speech provides stability in a democracy by ensuring that minority views are heard.

However, the low levels of political participation and the modern complexity of the state counter simplistic, deterministic relationships between information and democracy. After a comprehensive review of the deliberative democracy literature, Delli Carpini and colleagues (2004) concluded that "countering the optimism of proponents of deliberative democracy is a strong and persistent suspicion that public deliberation is so infrequent, unrepresentative, subject to conscious manipulation and unconscious bias, and disconnected from actual decision making as to make it at best an impractical mechanism for determining the public will, and at worst misleading or dangerous" (321).

With political knowledge among individuals steadily decreasing, some scholars suggest that the democratic ideal of engaged citizens is no longer realistic. In addition, "empirical research on deliberative democracy has lagged significantly behind theory" (Delli Carpini et al. 2004, 316). Examining the antecedents, actual acts, and consequences of deliberative democracy remain challenging activities, and this domain is understudied. Although some authors question its practical, real-world relevance (see, e.g., Robbin, Courtright, and Davis 2004; Oltmann 2014), the democracy theory remains theoretically and normatively significant.

\section{Libraries and Democracy}

The perspective of freedom of speech being a necessary component of democracy has been widely adopted in LIS literature. Both Sidney H. Ditzion (1947) and Jesse H. Shera (1949), in tracing the development of American public libraries, noted the close connection with democracy (see also McCook 2001). Many ALA position and policy statements explicitly name the protection and furtherance of democracy as one of the essential, foundational reasons for the existence and continuation of libraries (e.g., ALA 2014a, 2014d, 2014e). The ALA emphasizes that libraries "celebrate and preserve our democratic society by making available the widest possible range of viewpoints, opinions and ideas" (ALA 2014d, section 7). In linking IF and democracy, the ALA (2008) argues that "intellectual freedom is the basis for our democratic system. We expect our people to be self-governors. But to do so responsibly, our citizenry must be well-informed. Libraries provide the ideas and information ... to allow people to inform themselves" (ALA 2014C, par. 2). 
As Alex Byrne (2003) noted, there is a basic syllogism at the heart of nearly all discussions of democracy and libraries. This argument first states that "good libraries provide uninhibited access to information for all members of the community." Second, a "healthy democracy depends on an informed and participative community" (122). Thus, libraries facilitate democracy with their inclusive provision of information. Buschman (2005) noted that "libraries embody an essential element of democracy: a place where the ideal of unfettered communication and investigation exists in rudimentary form, allowing for critical and rational discussion of the issues of the day" (9-10).

Despite Byrne's (2003) exposition, he accepted the usual articulation of the relationship between libraries and democracy with little critical reflection. Many writers accept this relationship between freedom of speech and democracy uncritically and unreflectively (e.g., Doctor 1992; Smith 1995; Webster 1999; McCook 2001; Stielow 2001; Bertot 2003; Byrne 2003; Berry 2004; Brown 2004; Blakemore and Craglia 2006; Thompson 2008). For example, Nicole E. Brown (2004) simply noted that libraries are "integral to democratic governments" (169), and John N. Berry (2004) asserted that libraries were "created to inform our democracy" (8). Such claims are typically not explored, contested, or defended in any depth. Indeed, as Buschman (2007) contended, "the vast portion of this literature merely rehearses and repeats the basic ideas of Jefferson and Madison from 200 years ago" (1483; for additional critiques of this simplistic perspective, see Dervin 1994; Robbin et al. 2004).

\section{Individual Utility/ Autonomy}

The third predominant jurisprudential theory about freedom of speech argues that "freedom of expression is essential as a means of assuring individual self-fulfillment. The proper end of man [sic] is the realization of his character and potentialities as a human being. For the achievement of this self-realization the mind must be free. Hence suppression of belief, opinion, or other expression is . . a negation of man's essential nature" (Emerson 1970, 6). This theory posits that freedom of speech "is a right defiantly, robustly, and irreverently to speak one's mind just because it is one's mind," which "provides the speaker with an inner satisfaction and realization of self-identity essential to individual fulfillment" (Smolla 1993, 9, emphasis in original). (The argument from autonomy may be, as Julie Cohen [1996] implied, a particularly Western view.) In a 1969 case, Supreme Court Justice White argued that "the right of the public to receive suitable access to social, political, esthetic, moral, and other ideas and experiences is crucial" to the effectiveness of the Federal Communication Commission's fairness doctrine ${ }^{15}$ Here, the Court argued that citizens need access to diverse ideas for personal fulfillment and enlightenment.

15. Red Lion Broadcasting Co. v. FCC, 395 U.S. 367 (1969), 390. 
Susan J. Brison (1998) articulated several distinct but related variations of the autonomy argument, some of which are described here. First, autonomy can be seen from the perspective of Mill ([1869] 1921) as "freedom of governmental interference in some specified domain" (324). A second version of autonomy argues that "autonomous persons could not allow the state to protect them against the harm of coming to have false beliefs" without losing their autonomy (327; see also Scanlon 1972). Thomas Nagel (1995) similarly argued that "mental autonomy is restricted by shutting down both inputs [access to information] and outputs [expressions of speech]" (96). A third perspective on autonomy perceives it as an "ability to be rationally self-legislating" (330). This in turn connects to "the capacities, developed or undeveloped of persons ... which take as their self-critical object one's life and the way it is lived" (Richards 1989, 205).

For example, Eric Robertson (2011) explained that the First Amendment "protects those of us who may have no inclination to make our views known to the world, but would rather silently sample the many viewpoints that others make available to us" (324). "This right allows both those without the confidence to make their views publicly known and those with no viewpoint at all to develop a unique viewpoint. This chance for intellectual exploration and individual self-examination free from fear of government interference is exactly what the First Amendment is [for]," he further elaborated (328). The right to access information in a public library can allow people to think, imagine, create, and fully realize themselves.

\section{Libraries and Individual Autonomy}

Along these lines, Ronald D. Doctor (1992) claimed that a right to access is about empowering individuals, and Leah A. Lievrouw (2000) contended that "both access to channels and access to content are considered essential prerequisites for social and political participation in advanced societies" (155; see also Blakemore and Craglia 2006; Lor and Britz 2007). This is one of the foundations for the ALA's stance on IF (Rubin 2004; ALA 2014a, 2014c, 2014e). The ALA (2008) argued that "we recognize the power of information and ideas to inspire justice, to restore freedom and dignity to the oppressed, and to change the hearts and minds of the oppressors" (ALA 2014f, par. 11). The Library Bill of Rights (ALA 2014e, sec. 1) stated that "books and other library resources should be provided for the interest, information, and enlightenment of all people of the community the library serves," thus explicitly recognizing the value of individual empowerment.

\section{Discussion and Application of These Theories}

These three legal theories are the predominant legal explanations concerning the importance of freedom of speech and information access. In his book, Frederick Schauer (1982) was doubtful that any one argument is sufficient to fully support freedom of speech, but each one has particular strengths that protect certain aspects of speech. In other words, none of the 
three legal theories considered here should be adopted without reservation, but neither should they all be disregarded (see also Smolla 2005).

For example, the marketplace of ideas, with its clear depiction of sellers/speakers and buyers/listeners, provides a concise but fruitful analogy describing the communication and circulation of ideas through society. In particular, this theory acknowledges the important role of those receiving or accessing information (the buyers). It could be interesting to see which descriptions of a "marketplace" best fit actual, empirical situations in libraries; in turn, this might tell us something more about the value of speech and how to protect or enhance it. Perhaps, as Hopkins (1996) suggested, there are multiple marketplaces, each functioning somewhat differently. An examination of these different marketplaces could resolve ambiguity about the role of libraries in protecting and encouraging free speech.

To what extent are patrons "searching for truth" through their library use? Does the marketplace of ideas depict what occurs in libraries? If not, is it still a useful normative description of what we hope can occur in libraries? Tracking patron use of library resources could uncover different marketplaces in libraries or marketplaces that are lacking in diverse, enticing wares. To function as marketplaces of ideas, libraries must offer a wide range of perspectives in diverse formats. One could evaluate the diversity of viewpoints available at a library, on particular topics of contention, to determine whether the normative ideal of a marketplace is being met.

The argument from democracy is rarely addressed in a critical, rigorous manner in LIS. In his criticism of the LIS discipline's use of the argument from democracy, Buschman (2007) suggested that LIS "simply must engage democratic theory at a level deeper than the aposiopetic situation currently in place" (1484). LIS researchers could investigate the precise connections between libraries and democracy: What are the mechanisms by which libraries foster freedom of speech and meaningful democratic processes? Do both political and nonpolitical forms of speech flourish in libraries? A fairly simple approach would be to study a library's offerings during political campaigns, such as the upcoming presidential election. Does the library offer materials from both dominant parties as well as other parties? Do patrons come in seeking political information? The relationship of IF to a functioning democracy remains untraced. These sorts of questions have not been addressed in a systematic, research-oriented fashion, to the best of the author's knowledge.

Similarly, the argument from autonomy may be implicated in LIS philosophy, but it is rarely scrutinized. Some recent work suggests that reading enables one to be more comfortable with ambiguity or complexity (Djikic, Oatley, and Moldoveanu 2013). The ways in which IF promotes individual empowerment, however, are still opaque. This is an area ripe for further LIS research. Interviews with patrons about the significance or impact of library use could be connected to the autonomy theory, for example. 
Regardless of the paths chosen, it is clear that more work is needed to strengthen the connections between these legal theories and LIS. In particular, these legal theories tend to be utilized in a cursory manner in discussions of libraries. As Schauer (1982) argued, "To ignore what the law has done with respect to freedom of speech would be a mistake, because the law furnishes both doctrine and illuminating examples" (85). Therefore, what is needed is an expansion and a rigorous evaluation of these theories.

\section{References}

ALA (American Library Association). 2014a. "Core Values of Librarianship." http://www.ala.org/advocacy /intfreedom/statementspols/corevalues.

ALA (American Library Association). 2014b. "Intellectual Freedom Issues." http://www.ala.org/Template .cfm?Section $=$ ifissues $\&$ Template $=/$ ContentManagement $/$ ContentDisplay..$f m \&$ ContentID $=16426$ $5^{\# l i n k s .}$

ALA (American Library Association). 2014c. "Intellectual Freedom Q and A." https://www.ala.org/Template .cfm?Section=basics\&Template=/ContentManagement/ContentDisplay.. $\mathrm{fm} \&$ ContentID=60610.

ALA (American Library Association). 2014d. "Libraries: An American Value." http://www.ala.org/advocacy /intfreedom/statementspols/librariesamerican.

ALA (American Library Association). 2014e. "Library Bill of Rights." http://www.ala.org/advocacy/intfreedom /librarybill.

ALA (American Library Association). 2014f. "The Universal Right to Free Expression: An Interpretation of the Library Bill of Rights." http://www.ala.org/Template.cfm?Section=interpretations\&Template=/Content Management/ContentDisplay.cfm\&ContentID=8662.

Balkin, Jack M. 2004. "Digital Speech and Democratic Culture: A Theory of Freedom of Expression for the Information Society." NYU Law Review 79 (1): 1-55.

Barzun, Charles L. 2007. "Politics or Principle? Zechariah Chafee and the Social Interest in Free Speech." Brigham Young University Law Review 2007 (2): 259-325.

Bates, Marcia J. 2005. "An Introduction to Metatheories, Theories, and Models." In Theories of Information Behavior, edited by Karen E. Fisher, Sandra Erdelez, and Lynne E. F. McKechnie. Medford, NJ: Information Today.

Bell, Bernard W. 2001. "Filth, Filtering, and the First Amendment: Ruminations on Public Libraries' Use of Internet Filtering Software.” Federal Communications Law Journal 53 (2): 191-237.

Berry, John N. 2004. “To Inform Democracy." Library Journal 129 (19): 8.

Bertot, John Carlo. 2003. "The Multiple Dimensions of the Digital Divide: More than the Technology 'Haves' and 'Have Nots.'” Government Information Ouarterly 20 (2): 185-91.

Blakemore, Michael, and Max Craglia. 2006. "Access to Public-Sector Information in Europe: Policy, Rights, and Obligations." Information Society 22 (1): 13-24.

Blasi, Vincent. 1977. "The Checking Value in First Amendment Theory." American Bar Foundation Research Journal 2 (3): 521-649.

Blasi, Vincent. 1997. "Propter Honoris Respectum: Reading Holmes through the Lens of Schauer: The Abrams Dissent." Notre Dame Law Review 72 (5): 1343-61.

Blasi, Vincent. 2004. "Holmes and the Marketplace of Ideas." Supreme Court Review 2004 (1): 1-46. 
Blasi, Vincent. 2011. "Democratic Participation and the Freedom of Speech: A Response to Post and Weinstein.” Virginia Law Review 97 (3): 531-40.

Blitz, Marc J. 2006. "Constitutional Safeguards for Silent Experiments in Living: Libraries, the Right to Read, and a First Amendment Theory for an Unaccompanied Right to Receive Information." University of Missouri-Kansas City Law Review 74 (4): 799-882.

Bollinger, Lee C. 1986. The Tolerant Society: Freedom of Speech and Extremist Speech in America. New York: Oxford University Press.

Bork, Robert H. 1971. "Neutral Principles and Some First Amendment Problems." Indiana Law Journal 47 (1): $1-35$.

Braddon-Mitchell, David, and Caroline West. 2004. "What Is Free Speech?" Iournal of Political Philosophy $12(4): 437-60$.

Brison, Susan J. 1998. "The Autonomy Defense of Free Speech.” Ethics 108 (2): 312-39.

Brown, Nicole E. 2004. "The Shift from Apartheid to Democracy: Issues and Impacts on Public Libraries in Cape Town, South Africa." Libri 54 (3): 169-78.

Buckland, Michael. 1991. Information and Information Systems. Westport, CT: Greenwood.

Budd, John M. 2006. “Toward a Practical and Normative Ethics for Librarianship." Libraru Ouarterly 76 (3): 251-269.

Burden, Paul R. 2000. “The Key to Intellectual Freedom Is Universal Access to Information.” American Libraries 31 (8): 46-49.

Burnett, Gary, Paul T. Jaeger, and Kim M. Thompson. 2008. "Normative Behavior and Information: The Social Aspects of Information Access." Library and Information Science Research 30 (1): 56-66.

Buschman, John. 2005. "Libraries and the Decline of Public Purposes." Public Library Ouarterly 24 (1): 1-12. Buschman, John. 2007. "Democratic Theory in Library Information Science: Toward an Emendation.” Iournal of the American Societu for Information Science and Technoloay 58 (10): 1483-96.

Byrne, Alex. 2003. "Necromancy or Life Support? Libraries, Democracy, and the Concerned Intellectual." Library Management 24 (3): 116-25.

Chafee, Zechariah, Jr. 1941. Free Speech in the United States. Cambridge, MA: Harvard University Press. Chambers, Simone. 2003. "Deliberative Democratic Theory." Annual Review of Political Science 6:307-26.

Chevigny, Paul. 1988. More Speech: Dialogue Rights and Modern Liberty. Philadelphia: Temple University Press.

Coase, Ronald H. 1974. "The Market for Goods and the Market for Ideas.” American Economic Review 64 (2): 384-91.

Cohen, Julie. 1996. "A Right to Read Anonymously: A Closer Look at 'Copyright Management' in Cyberspace." Connecticut Law Review 28 (4): 981-1039.

Delli Carpini, Michael X., Fay L. Cook, and Lawrence R. Jacobs. 2004. "Public Deliberation, Discursive Participation, and Citizen Engagement: A Review of the Empirical Literature." Annual Review of Political Science 7:315-44.

Dervin, Brenda. 1994. “Information $\leftarrow \rightarrow$ Democracy: An Examination of Underlying Assumptions.” Journal of the American Societu for Information Science 45 (6): 369-85.

Ditzion, Sidney H. 1947. Arsenals of a Democratic Culture: A Social History of the American Public Library Movement in New England and the Middle States from 1850-1900. Chicago: American Library Association.

Djikic, Maja, Keith Oatley, and Mihnea C. Moldoveanu. 2013. "Opening the Closed Mind: The Effect of Exposure to Literature on the Need for Closure." Creativitu Research Journal 25 (2): 149-54. 
Doctor, Ronald D. 1992. "Social Equity and Information Technologies: Moving toward Information Democracy." Annual Review of Information Science and Technology 27:43-96.

Doyle, Tony. 2001. "A Utilitarian Case for Intellectual Freedom in Libraries.” Library Ouarterly 71 (1): 44-71.

Doyle, Tony. 2002. "A Critical Discussion of the 'Ethical Presuppositions behind the Library Bill of Rights."” Library Ouarterly $72(3):$ 275-93.

Edmundson, William A. 2005. "Introduction." In The Blackwell Guide to the Philosophy of Law and Legal Theory, edited by Martin P. Golding and William A. Edmundson. Oxford: Blackwell.

Emerson, Thomas I. 1970. The System of Freedom of Expression. New York: Vintage.

Fallis, Don. 2007. “Information Ethics for Twenty-First Century Library Professionals.” Libraru Hi-Tech 25 (1): $23-36$.

Fallis, Don, and Mathiesen, Kay. 2001. "Response to Doyle." Libraru Ouarterlu 71 (3): 437-38.

Fricke, Martin, Kay Mathiesen, and Don Fallis. 2000. "The Ethical Presuppositions behind the Library Bill of Rights." Library Ouarterly 70 (4): 468-91.

Good, Joseph. 2006. "The Hottest Place in Hell: The Crisis of Neutrality in Contemporary Librarianship." Progressive Librarian 28:25-29.

Gordon, Jill. 1997. “John Stuart Mill and the 'Marketplace of Ideas.'” Social Theory and Practice 23 (2): 23549.

Gorman, Michael. 2000. Our Enduring Values. Chicago: American Library Association.

Hauptman, Robert. 2002. Ethics and Librarianship. Jefferson, NC: McFarland.

Heckart, Ronald J. 1991. "The Library as a Marketplace of Ideas." Colleae and Research Libraries 52 (6): 491-505.

Hopkins, W. Wat. 1996. “The Supreme Court Defines the Marketplace of Ideas.” Lournalism and Mass Communication Ouarterly 73 (1): 40-52.

Jaeger, Paul T., and Gary Burnett. 2005. "Information Access and Exchange among Small Worlds in a Democratic Society: The Role of Policy in Shaping Information Behavior in the Post-9/11 United States." Library Ouarterly $75(4):$ 464-95.

Jaeger, Paul T., Ursula Gorham, John Carlo Bertot, and Lindsay C. Sarin. 2013. “Democracy, Neutrality, and Value Demonstration in the Age of Austerity." Libraru Ouarterly 83 (4): 368-82.

Jensen, Robert. 2004. "The Myth of the Neutral Professional." Progressive Librarian 24:28-34.

Jones, Barbara M. 1999. Libraries, Access, and Intellectual Freedom: Developing Policies for Public and Academic Libraries. Chicago: American Library Association.

Klinefelter, Anne. 2010. "First Amendment Limits on Library Collection Management." Law Library Journal $102(3): 343-74$.

Knox, Emily. 2014. "Supporting Intellectual Freedom: Symbolic Capital and Practical Philosophy in Librarianship." Library Ouarterly 84 (1): 8-21.

Kranich, Nancy, ed. 2001. Libraries and Democracy: The Cornerstones of Liberty. Chicago: American Library Association.

Krug, Judith F. 2002. "ALA and Intellectual Freedom.” In Intellectual Freedom Manual, 6th ed. Chicago: Office of Intellectual Freedom, ALA.

Lievrouw, Leah A. 2000. “The Information Environment and Universal Service.” Information Society 16 (4): 155-59.

Lor, Peter J., and Johannes J. Britz. 2007. "Is a Knowledge Society Possible without Freedom of Access to Information?" Journal of Information Science 22 (4): 387-97.

Mart, Susan N. 2003. “The Right to Receive Information.” Law Library Journal 95 (2): 175-89. 
Mathiesen, Kay, and Don Fallis. 2008. "Information Ethics and the Library Profession." In The Handbook of Information and Computer Ethics, edited by Kenneth E. Himma and Herman T. Tavanni. Hoboken, NJ: Wiley.

McCook, Kathleen de la Peña. 2001. Introduction to Public Librarianship, 2nd ed. New York: Neal-Shuman.

McDonald, Barry P. 2004. "The First Amendment and the Free Flow of Information: Towards a Realistic Right to Gather Information in the Information Age.” Ohio State Law Journal 65 (2): 249-356.

McGrath, W. E. 2002. “Introduction.” Library Trends 50 (3): 309-16.

McKechnie, L. E. F., and Pettigrew, K. E. 2002. "Surveying the Use of Theory in Library and Information Science Research: A Disciplinary Perspective." Library Trends 50 (2): 406-17.

Meiklejohn, Alexander. 1961. “The First Amendment Is an Absolute.” Supreme Court Review 1961:245-66. Mill, John Stuart. (1869) 1921. On Liberty. London: Longmans, Green.

Nagel, Thomas. 1995. "Personal Rights and Public Space." Philosophy and Public Affairs 24 (2): 83-107.

Napoli, Phillip M. 1999. "The Marketplace of Ideas Metaphor in Communications Regulation.” Journal of Communication 49 (4): 151-69.

Oltmann, Shannon M. 2014. "Data, Censorship, and Politics: Analyzing the Restricted Flow of Information in Federal Scientific Policy Development." Iournal of the Association for Information Science and Technoloau 66 (1): 144-61.

Post, Robert. 2011a. "Participatory Democracy and Free Speech." Virginia Law Review 97 (3): 477-89.

Post, Robert. 2011b. "Participatory Democracy as a Theory of Free Speech: A Reply." Virginia Law Review $97(3): 617-32$.

Raikka, Juha. 2003. "The Argument from Truth as a Basis for Legislation Concerning Freedom of Speech." Trames 7 (4): 249-56.

Richards, David A. J. 1989. “Autonomy in Law.” In The Inner Citadel: Essays on Individual Autonomy, edited by J. Christman. New York: Oxford University Press.

Riley, Jonathan. 2005. “J. S. Mill's Doctrine of Freedom of Expression.” Utilitas 17 (2): 147-79.

Robbin, Alice, Courtney Courtright, and Leah Davis. 2004. "ICTs and Political Life." In Annual Review of Information Science and Technology, edited by Blaise Cronin. Medford, NJ: Information Today.

Robertson, Eric. 2011. "A Fundamental Right to Read: Reader Privacy Protections in the U.S. Constitution." University of Colorado Law Review 82 (1): 307-30.

Ross, Catherine J. 1999. “An Emerging Right for Mature Minors to Receive Information.” University of Pennsylvania Journal of Constitutional Law 2 (1): 223-75.

Rubin, Richard E. 2004. Foundations of Library and Information Science, 2nd ed. New York: Neal-Schuman. Scanlon, T. M. 1972. "A Theory of Freedom of Expression.” Philosophy and Public Affairs 1 (2): 204-26. Schauer, Frederick. 1982. Free Speech: A Philosophical Enquiry. Cambridge: Cambridge University Press. Schauer, Frederick, 1986. "The Role of the People in First Amendment Theory." California Law Review 74 (3): $761-88$.

Shera, Jesse H. 1949. Foundations of the Public Library: The Origins of the Public Library Movement in New England, 1629-1855. Chicago: University of Chicago Press.

Shiffrin, Steven H. 1990. The First Amendment, Democracy, and Romance. Princeton, NJ: Princeton University Press.

Shiffrin, Steven. 2011. "Dissent, Democratic Participation, and First Amendment Methodology." Virginia Law Review 67 (3): 559-65.

Smith, Elizabeth S. 1995. "Equal Information Access and the Evolution of American Democracy." Journal of Educational Media and Library Sciences 33 (2): 158-71. 
Smolla, Rodney A. 1992. Free Speech in an Open Society. New York: Knopf.

Smolla, Rodney A. 1993. "Freedom of Speech for Libraries and Librarians." Law Library Journal 85 (1): 71-79. Smolla, Rodney A. 2005. Smolla and Nimmer on Freedom of Speech, vols. 1 and 2. Danvers, MA: Thomson/West. Stielow, Frederick. 2001. "Reconsidering Arsenals of a Democratic Culture." In Libraries: Cornerstone of American Democracy, edited by Nancy C. Kranich. Chicago: American Library Association.

Thompson, Kim M. 2008. "The U.S. Information Infrastructure and Libraries: A Case Study in Democracy." Library Review 57 (2): 96-106.

Volokh, Eugene. 2011. "The Trouble with 'Public Discourse' as a Limitation on Free Speech Rights." Virginia Law Review 97 (3): 567-94.

Webster, Frank. 1999. "Knowledgeability and Democracy in an Information Age." Library Review 48 (8): $373-83$.

Shannon M. Oltmann: assistant professor in the School of Information Science at the University of Kentucky. Oltmann earned her PhD from the School of Library and Information Science at Indiana University. Her research interests include freedom of speech, intellectual freedom, information policy, public libraries, and qualitative research methods. Her work has been published in the Journal of the American Society for Information Science and Technology, Libri, and Science and Engineering Ethics. She is part of the multi-institution research team Mapping Information Access. E-mail: shannon .oltmann@uky.edu. 